\title{
A Myth of Kinship? Reinterpreting Lakota Conceptualization of Kin Relationships vis-à-vis 19th and 20th Century Historical Narratives
}

\section{Kellie Hogue}

\section{OpenEdition}

\section{Journals}

Electronic version

URL: https://journals.openedition.org/jsa/11529

DOI: 10.4000/jsa. 11529

ISSN: $1957-7842$

Publisher

Société des américanistes

\section{Printed version}

Date of publication: 5 December 2010

Number of pages: 101-131

ISSN: 0037-9174

\section{Electronic reference}

Kellie Hogue, "A Myth of Kinship? Reinterpreting Lakota Conceptualization of Kin Relationships vis-àvis 19th and 20th Century Historical Narratives ", Journal de la Société des américanistes [Online], 96-2 I 2010, Online since 10 December 2014, connection on 03 September 2022. URL: http:// journals.openedition.org/jsa/11529; DOl: https://doi.org/10.4000/jsa.11529 


\title{
A MYTH OF KINSHIP? REINTERPRETING LAKOTA CONCEPTUALIZATION OF KIN RELATIONSHIPS $V I S-\hat{A}-V I S$ 19th AND 20th CENTURY HISTORICAL NARRATIVES
}

\author{
Kellie HOGUE *
}

Drawing upon the theoretical perspectives of Claude Lévi-Strauss, Raymond DeMallie, and Emmanuel Désveaux, this paper combines a structuralist approach with symbolic anthropology in an attempt to reinterpret historical categorization of Lakota kinship through an examination of the relationship between the Lakota and a pervasive representative of the non-material world in Lakota life, the bird. To begin this reinterpretation, I identify the existence of a special relationship between the Lakota and birds through a review of relevant myths. Then, I present qualitative data about the symbolic language of feathers found in the writings of 19th and 20th century Lakota people like Luther Standing Bear, White Bull, and Black Elk. Next, I explain how these symbols serve as intermediaries between the material and non-material cognitive worlds of the Lakota and birds. After considering the evidence presented, I suggest that 19th and 20 th century Lakota notions of kinship were more complex than has been historically depicted because they took into consideration both human and non-human relationships. My goal is to provocatively prompt a reconsideration of the historical categorization of Lakota ideas of kinship to take into account the influence of nonhuman relations on social behavior and organization. [Key words: Lakota, kinship, structuralism, symbolic anthropology, birds.]

Un mythe de parenté? Réinterprétation de la conceptualisation des liens de parenté chez les Lakota à partir de récits historiques des $x x^{2}$ et $x x^{e}$ siècles. Partant des perspectives théoriques de Claude Lévi-Strauss, Raymond DeMallie et Emmanuel Désveaux, cet article combine l'approche structuraliste avec l'anthropologie symbolique pour proposer une réinterprétation de la catégorie historique de "parenté » chez les Lakota en s'appuyant sur la relation entre le monde des Lakota et celui, non matériel, des oiseaux, très important pour eux. Comme point de départ de cette réinterprétation, l'existence d'une relation particulière entre les Lakota et les oiseaux est révélée à travers l'étude de mythes ad hoc. Vient ensuite une présentation des données qualitatives sur le langage symbolique des plumes tel qu’il apparaît dans les écrits de Luther Standing Bear, White

*Indiana University, Department of Anthropology, Bloomington, 47405, Indiana, USA [kjhogue@indiana.edu].

Journal de la Société des Américanistes, 2010,96-2, pp. 101-131. O Société des Américanistes. 
Bull et Black Elk, datant des $\mathrm{xIx}^{\mathrm{e}} \mathrm{et} \mathrm{xx}^{\mathrm{e}}$ siècles. Suit une explication sur la façon dont ces symboles servent d'intermédiaires entre le monde cognitif matériel des Lakota et celui, non matériel, des oiseaux. Après l'exposé des données, on suggère que la notion de " parenté » chez les Lakota des $\mathrm{XIX}^{\mathrm{e}}$ et $\mathrm{Xx}^{\mathrm{e}}$ siècles était bien plus complexe que ce que l'histoire nous a décrit, parce que ces derniers prennent en compte les relations entre humains, mais aussi entre humains et non humains. L'objectif de ce travail est donc de reconsidérer la catégorie de " parenté » chez les Lakota à partir d'un nouvel éclairage qui tient compte de l'influence des relations non humaines sur les attitudes et l'organisation sociale. [Mots-clés: Lakota, parenté, structuralisme, anthropologie symbolique, oiseaux.]

¿Un mito de parentesco? Reinterpretando la conceptualización lakota de las relaciones de parentesco por medio de narrativas históricas de los siglos $x z x$ y $x x$. Con base en las perspectivas teóricas de Lévi-Strauss, DeMallie y Désveaux, este trabajo combina un enfoque estructuralista con la antropología simbólica, eso con el fin de reinterpretar la categoría histórica de " parentesco » entre los lakotas a partir de la relación entre su mundo y aquel, muy importante para ellos, no-material de las aves. Como punto de partida de esta reinterpretación, se establece la existencia de una relación especial entre los lakotas y las aves mediante el estudio de unos mitos. Se presentan luego datos cualitativos acerca del lenguaje simbólico de las plumas tales como aparecen en los escritos de Luther Standing Bear, White Bull y Black Elk (siglos xix y xx). Sigue una explicación sobre la manera en que estos símbolos sirven de intermediarios entre el mundo cognitivo material de los lakotas y aquel, no material, de las aves. Posteriormente, se sugiere que la noción de parentesco entre los lakotas de los siglos XIX y xx era bastante más compleja que lo que la historia registró, ya que ellos toman en cuenta las relaciones entre humanos, pero también entre humanos y no-humanos. El objetivo de este estudio es pues reconsiderar la categoría de " parentesco » entre los lakotas a partir de la luz nueva que echan las relaciones humanas/no-humanas sobre el comportamiento y la organización social. [Palabras claves: lakota, parentesco, estructuralismo, antropología simbólica, aves.]

\section{INTRODUCTION}

If North American peoples can regard the sun in some cases as a « father » and benefactor and in others as a cannibalistic monster thirsting for human flesh and blood,

there seems to be no limit to the variety of interpretations to be expected when it is something as specific as a subvariety of a plant or bird which is in question. (Claude Lévi-Strauss, The savage mind, 1966)

In The savage mind (1966), Claude Lévi-Strauss identifies the complexities involved in the study of human-animal relationships among indigenous peoples. Drawing on a wide variety of source material from all over the globe, he suggests that « the concrete relations between man and other living creatures sometimes, especially in civilizations in which science means "natural science", colour the entire universe of scientific knowledge with their own emotional tone" 
(Lévi-Strauss 1966, p. 38). He presents an interesting selection of examples as evidence for this phenomenon, such as the notion that the Navajo separate birds into two groups - male and female - based upon cultural meanings rather than gender, the belief of the Hidatsa that they were given instructions on how to hunt eagles by mythical animals who resembled bears, and that « the position of the eagle would be incomprehensible were it not known in Osage thought that eagles are associated with lightning, lightning with fire, fire with coal and coal with the earth » (ibid., pp. 39, 50, 59). He identifies three specific difficulties that make the study of human-animal relationships among indigenous peoples especially problematic: 1) we cannot be exactly sure what animal, plant, or bird is being represented due to locational and geographic variations, 2) there is an infinite number of possibilities that a species could represent within the symbolic system of each social group, and 3) the "natural complexity " of these relationships suggests that it is more important that they simply exist, rather than understanding the specific way in which those relationships manifest themselves (ibid., pp. 65-66). Using the example of totemic clan continuity and discontinuity over time, he gives special consideration to the problem of demographic changes upon those relationships that are lived (those that are fully «totemic ») in diachronic and synchronic terms, noting that language is especially responsive to change in this respect; for the understanding of relationships between humans and animals is conceptualized through language. Lévi-Strauss then demonstrates the relationship between myth, social structure, and camp configuration by bringing an Osage origin myth into historical context, situating it both diachronically and synchronically, and concluding that it is possible to observe the manner in which those three dimensions of Osage culture form a system that links historical myth with lived behavior through " a structural adjustment of the historical process » (ibid., pp. 68-69). In short, he illustrates the existence of direct connection between myth and reality among humans who participate in a clan system that uses animals as identifiers.

Whereas Lévi-Strauss utilized the clan system as the structural symbol through which diachronic and synchronic change mediates between myth and reality, in this article I focus on a symbol and demonstrate the cultural and social breadth of its mediation. Through the process of identifying the multiple aspects (in Lévi-Straussian terms, the associative codes) of the chosen symbol (species of birds) as just one of a variety of kaleidoscopic domains (genus) located upon a particular axis, I attempt to reveal the integration of this symbol within a core aspect of historic Sioux society, kinship. Put another way: instead of seeing birds as totems and then analyzing how the various totems as clans explain the demographic and kinship shifts among a particular group, I use birds as a cultural symbol to suggest the existence of a larger conceptualization of kin relationships in the Lakota context than has been previously documented. Thus, drawing upon the theoretical perspectives of Claude Lévi-Strauss, Raymond DeMallie, and 
Emmanuel Désveaux, this paper combines a structuralist approach with symbolic anthropology in an attempt to reinterpret historical categorization of Lakota kinship through an examination of the relationship between the Lakota and birds.

To begin this reinterpretation, I present qualitative data about birds and their feathers found in the works of 19 th and 20th century Lakota people. Then, I identify the existence of a special relationship between the Lakota and birds through a review of relevant myths. Next, I attempt to explain how these symbols serve as intermediaries between the material and non-material cognitive worlds of the Lakota and birds. After considering the evidence presented, I suggest that historic Lakota notions of kinship were more complex than has been depicted because they took into consideration both human and non-human relationships. My goal is to provocatively prompt a reconsideration of the historical categorization of Lakota ideas of kinship to take into account the influence of nonhuman relations on social behavior and organization. I posit that birds were persons in Lakota culture; therefore, Sioux people interacted with them (and other animals) as fellow social beings. Put succinctly: because they « related » to birds, they perceived birds as kin.

\section{RECONCEPTUALIZING SOCIAL INTERACTION IN A CULTURAL SENSE}

Historically, anthropologists of the Americanist tradition have tended to identify kinship structures and social organization solely through an examination of human-to-human consanguineal, affinal, and adoptive relationships. Indeed, the vast amount of literature produced generally on American Indian kinship focuses primarily upon the human network of relationships that constitute social organization. Concomitantly, the concept of kinship has been a central and enduring aspect of research on pre-contact and historic Lakota life. In particular two anthropologists, Raymond J. DeMallie and Emmanuel Désveaux, have continued to push beyond the limits of academic inquiry as it pertains to notions of American Indian kinship and social organization.

When discussing culturally specific understandings of kin relations, DeMallie suggests that « for the Sioux, kinship is not confined to the classification of relationship through links of marriage and descent, but is more broadly defined to embrace all significant social interaction » (DeMallie 1994, p. 126). Further, although « [c]ommonality of language was the native criterion for defining the boundaries of Sioux society », because all individuals within this speech community participated in the ongoing process of "relating ", the mandatory " prerequisite for social interaction ", Sioux society is best " conceptualized as comprising a vast network of ego-centered kindred » (DeMallie 2009, p. 188). Three types of kin relationships made this social web of significance possible: 
biological, genealogical, and informal. Approaching the study of Sioux kinship symbolically is valid, for, although DeMallie's perspective acknowledges that there were " no common understandings " of symbols " whose meanings the whites and Lakotas were incapable of communicating » (DeMallie 1982, p. 404), when discussing historical analyses of the Lakota Ghost Dance, he has argued that there exists a « reluctance to take seriously the symbolic content of Indian cultures - in this instance, to allow the Lakota their own legitimate perspective » (DeMallie 1984, p. 388). Further, he suggests that symbolic anthropology is especially useful in " attempts to isolate differing significant symbols - units of meaning - that define perspectives on reality within different cultural systems » (ibid., p. 389). Using the symbolic approach as suggested by DeMallie allows me to attempt to " delineate the collective understandings » and " cognitive worlds » that characterize human relationships with birds in a definitively Lakota sense. Additionally, although I am using birds to attempt to identify a collective understanding within the Lakota cognitive world, I am also aware that birds are part of a larger system that includes other animals (especially the buffalo) and other human groups. This awareness comes from DeMallie's statement that " the Lakotas thought of the land, the animals, and the people as a single system, no part of which could change without affecting the others " (ibid., p. 391). Of great importance to this discussion is the idea that «symbols embody cultural definitions and relationships; they describe the universe in a unique way, distinctive of a particular social group » (DeMallie 1994, p. 126).

When teamed with Désveaux's recent call for a re-examination and reinterpretation of the historical categorization of American Indian groups as a way to deepen our understanding of social organization and kin relationships, this article effectively contributes to a renewed effort to find ways to comprehend the Lakota cognitive world. While it is clear that Lakota viewed human-to-human kin relationships as important, they also actively expressed strong relationships with particular animals and birds, for accounts, stories, and cultural interpretations of the activities and behaviors of these non-human counterparts (and other animals) permeate accounts of 19 th and 20th century Lakota life. One method for understanding this relationship can be derived through attempts to demonstrate the depth and breadth of this human/non-human kinship-like network through the use of comparative perspectives that take into account the human, non-human, and natural worlds. For, if the historical Lakota envisioned themselves as having a special relationship with birds, then it is necessary to consider the manner in which they coordinated their lives in accordance with the natural world, such as the seasons, the weather, and other natural events.

In Quadratura Americana: essai d'anthropologie lévi-straussienne (2001), Désveaux takes such a comparative perspective to illustrate the relatedness of humans, non-humans, and the natural world. Noting that " l'aigle est un migrateur $"$, he suggests that one additional factor that contributed to the migratory 
movements of Lakota people are seasonal changes (Désveaux 2001, p. 298). Building on the model that Lévi-Strauss (1962) developed in Le totémisme aujourd hui, he suggests that animals and birds themselves played a critical role beyond the simple use of animals-as-totems in society and advocates a more global approach. Similar to Lévi-Strauss's use of clans as the mechanism through which to view the interrelatedness of human-animal existence, in one example he uses the concept of moieties to demonstrate the connections between the seasons, social groups, animals, games, and sexuality (Désveaux 2001, p. 299). Désveaux advances the notion that the individual has access to what he labels an "axe animique " that exists between the totemic world and social world. This axis allows the individual to balance the material world with the non-material world (ibid., p. 391). This approach is useful in understanding the mechanism that allowed the historical Lakota to perceive their relatedness to both other humans and non-humans. Drawing from Désveaux's example, I attempt to demonstrate the diversity of birds as a symbolic domain situated on this axe animique. As one of the most popular symbols of a non-human species that actively and physically connected the material and non-material worlds through flight, their feathers were interpreted as objects of power, not only present in daily life, but also in myth and legend.

Ultimately, the crucial underlying notion at work here is that I aim to demonstrate that Sioux people perceived their engagement with birds (and by extension, all other animals and non-human beings) as social interaction in a cultural sense. Further, as a result of this perception, they " related » to birds socially. Since to be social is to have kin relationships with another, I therefore suggest that Sioux people perceived birds as kin (expressed in myth and story as fellow "two-leggeds»). For, when not representing themselves, birds are consistently present in social life through the use of their feathers. Whether single or clustered together, feathers were much more than the simple adornment or fetish commodity that has come to be a stereotypical representation of the American Indian. Ceremonial and everyday uses of feathers served to symbolize their relationship with birds, and Lakota people collected and wore feathers of various birds as a way to obtain and make use of extra-human powers.

\section{CONSTRUCTING THE PROPER NEST}

Scholarly literature on the Lakota is extremely varied and includes a wide range of historical and contemporary topics: children's literature, animal culture, Christianity, ethics, social usages, etiquette, family, marriage, women, death and dying, history, languages, music, recreation, law, and fine arts. Given the breadth of this extensive corpus, to demonstrate the relatedness of Sioux people and birds I use a variety of methodological approaches - ethnohistorical, symbolic, and 
structuralist - in addition to limiting my selection of source materials to only those that best express a sense of cultural verisimilitude.

Given that the literature on Sioux kinship is grounded heavily in the experiences of Lakota people from the late 1800 s to the early to mid $1900 \mathrm{~s}$, for this essay I draw solely upon the works of 19 th and 20th century Lakota people and rely heavily upon the memoirs of Luther Standing Bear and the edited writings of James R. Walker. Vestal (1933) believed that Standing Bear provided « excellent accounts » of Lakota life « as he knew it " and DeMallie (1974) suggests that he exemplified a "generation of Indians who were raised in their traditional culture, were educated in boarding schools, and who made the transition to late nineteenth-century American civilization 》 (ibid., p. 178). Standing Bear's texts - My people, the Sioux (1975 [1928]), My indian boyhood (1988a [1931]), Land of the spotted eagle (1978 [1933]), and Stories of the Sioux (1988b [1934]) - form a unique bounded cultural set that gives us a broad and thick description of Lakota life during a time of great transition. Similarly, the edited writings of Walker, a physician at Pine Ridge at the turn of the century, are " still regarded as essential source material on Lakota society " (Hurtado 1985). Other significant resources for socio-cultural data include The sixth grandfather: Black Elk's teachings given to John Niehardt (DeMallie 1984), Warpath: the true story of the fighting Sioux told in a biography of chief White Bull (Vestal 1984), and Teton Sioux music and culture (Densmore 1992 [1918]). Thus, in keeping with my goal of reconsidering specifically Lakota conceptualizations of kinship, I have limited my sources to the appropriate historical period to ensure the validity and credibility of my argument.

To extract details concerning Lakota conceptualization of birds requires an ethnohistorically grounded close reading of the text-based materials available on the Lakota, paying special attention to 1) stories and myths that feature birds and 2) cultural meanings associated with birds and their feathers. In the writings of the 19th and 20th century Lakota, birds frequently represent themselves, or their presence is represented by their feathers. To take just one example that features a prairie owl: in 1873 a shaman named Little, along with his wife, passed away. Their deaths were noted in White Bull's winter count. They were both very old and the woman died first. The shaman no longer desired to live without his wife and said that before he would die, something would emerge from his body. So he " placed a buffalo chip before him and made some gestures ". What looked like a small bird - but that eventually grew into a prairie owl - came out of his mouth. He then asked that when he finally expired, the bird be allowed to go free (Vestal 1984 , p. 269). It may have been that the man had a spirit dwelling inside him that was released upon his death. Another interpretation of this story is as follows: the emergence of a bird from the shaman's body suggests that he had transformed into a bird, leaving his physical body behind. The bird, as a messenger of Wakan (the holy) and the closest approximation of natural kin, when set free after his 
death would ensure the shaman's continued existence as a Sioux despite the fact that he no longer had human form. In this context, then, the bird could be said to symbolize the shaman's soul and culturally, the prairie owl could be said to be a representative of those Sioux who were once human but had passed on. Further, the prairie owl could have been the original source of the shaman's powers in life, and his transformation from human to bird would be the restoration of those powers back into the original being that appeared to the shaman at an earlier time in his life by means of a vision. The return of these powers would then make them available to another human being and also serve to make the prairie owl an object of serious cultural and symbolic significance.

But these ethnohistorical details, articulated in cultural and symbolic terms, only take us so far. A structuralist approach allows for a potentially deeper understanding of the transformation from human to bird. To further comprehend the cultural logic that creates the historically specific context for transformation from human to bird, in his Osage example Lévi-Strauss provides a highly adaptable model that can be used to connect myth with history and to demonstrate the impact of myth on structural institutions within a particular social group in the form of social behavior. Thus, I will replicate his method and use a set of stories about birds and humans to draw a connection between historical myth and lived behavior in the Lakota context.

\section{SIOUX ETHNO-ORNITHOLOGY}

Let us now turn to a discussion of the cultural and symbolic representations of birds in the historical writings of 19th and 20th century Lakota people. First, I bring together statements and comments about birds in general. Then I present ethnohistorical data separately about each of the following birds: crane, crow, duck, eagle, hawk, kingbird, magpie, meadowlark, owl, prairie chicken, swallow, white goose, and woodpecker.

\section{Birds in general}

Although they identified relationships with animals (the bear and the buffalo, for example), from the wealth of ethnohistorical data available it is evident that the Lakota participated in a special relationship with birds. In My Indian boyhood, Luther Standing Bear (1988a [1931], p. 72) tells us that in their desire to obtain the powers associated with birds and animals, the Lakota «formed societies and lodges named after birds and animals » and then « strove to acquire their powers ». As Luther Standing Bear's quote implies, it was generally accepted that Indian groups acknowledged a sense of relatedness with what might appear to us as non-human beings. In this social context, Sioux people 
took a number of clues from birds that resulted in social behaviors and attitudes.

Thunder Tail identifies certain activities that all birds participate in as important references to Lakota life. Birds, like the Lakota, « make a nest to raise their children in ". If an intruder comes, « they rise up against him ", « cry out vigorously " or "fly out to pursue him ». All these responses are for the protection of their children, so they are not captured. Whether in camp or participating in warfare, they nested and protected their young just as birds did (Rice 1998, p. 161). From these comments, we could interpret the Lakota camp as a bird's nest, Lakota parents as the adult birds, and Lakota children as baby birds in need of both food and protection. This is confirmed by the statement: "We make our people like the birds » (ibid., p. 162). Black Elk offers more evidence for this idea of homes as « nests »:

Everything is now too square. The sacred hoop is vanishing among the people. We get even tents that are square and live in them. Even the birds and their nests are round. You take the bird's eggs and put them in a square nest and the mother bird just won't stay there. We Indians are relative-like to the birds. Everything tries to be round - the world is round. We Indians have been put here [to be] like the wilds and we cooperate with them. Their eggs of generations are in the sacred hoop to hatch out. Now the white man has taken away our nest and put us in a box and here they ask us to hatch our children, but we cannot do it. We are vanishing in this box. (DeMallie 1984, p. 291)

Birds were also admired for their persistence in protecting their nests (and their young) courageously. Thunder Tail comments that birds, although they do not have weapons, " fight vigorously and wound many of their enemies, and even kill them in order to protect their own ». The Lakota so greatly believed in the strength of their relationship with birds, Thunder Tail suggested, that they imitated the behaviors of birds when in battle. Birds, by virtue of their physiology, can rarely kill an opponent or prey in one pass; similarly when in battle the Lakota would count coup upon their enemies multiple times before seriously wounding them or killing them. "And so in battle the people act like birds ", said Thunder Tail. « They make war medicines from the bodies of birds and they use that power for energy in battle and for couping the enemy " (Rice 1998, p. 162). From this except from Thunder Tail, we can conclude that the Lakota saw themselves as living in a manner that was very similar to the way the birds lived. Further, Standing Bear was taught to carefully watch the habits of birds while learning to hunt. He writes:

We watched them closely, for they taught us many things. Birds are graceful beings, and the Indian loves beauty in movement. In his dances the Indian is highly imitative, and many of his steps he gets from the birds. Besides, they have virtues such as industry, kindness, affection, and pride. They have also keen senses that the Indian admires. (Standing Bear 1975, p. 67) 
Not only did they live like birds did, there was also a time when birds and people could talk to one another; a " time when bird and animal life communicated with man » (Standing Bear 1988a [1931], p. 70). Birds, such as the prairie chicken, meadowlark, and crow, are able to « make sounds that can be interpreted into Sioux words » (ibid.). The sounds of birds can then be interpreted as Sioux words, and to extend this further, the songs of birds could be interpreted as the songs of the Sioux, and the songs of the Sioux could be interpreted as the songs of the birds. Given that language was a critical marker of Lakota identity, it is possible to suggest that birds were also taken to be persons in the Sioux sense. However, beyond birds in general, the feathers of birds were also imbued with culturally specific meanings.

For example, to wave feathers over someone is an acknowledgment or wish for bravery, a promise of help, or a blessing of prosperity, peace, and happiness (Walker 1991, p. 213). When used for ritual, feathers may also represent flames coming out of the mouth of a bear (DeMallie 1984, p. 179). The gift of feathers is proof of success on the warpath (Deloria 1988, p. 90). How feathers are worn can be of great significance. Wearing feathers was a voluntary activity among Lakota men, not just for chiefs and warriors. Feathers were not worn all the time. "Some white people have the idea that Indians wear feathers all the time - in fact, I imagine they have an idea that we go to bed with them on ", writes Luther Standing Bear. "We wore feathers only when we were going to dress up - just as white people put on their evening clothes for a party or dance » (Standing Bear 1975 [1928], p. 78). Although the wearing of feathers was a voluntary activity, sometimes reserved for special occasions and sometimes for everyday, the relationship between birds and the Lakota transcended the mere wearing of feathers and penetrated deeply into their perceptions of social organization and the fundamental aspects of life as it was lived.

Feathers transmitted the status and experiences of a person. In this " language » of feathers, a Lakota could « read » the accomplishments and status of a man just by looking at him. For instance, feathers dyed red are an indication that the wearer was injured in battle (Standing Bear 1988a [1931], pp. 84-85). While feathers often were an expression of the desire to obtain and use certain extra-human powers, they also were an acknowledgment of the special qualities of a particular bird. Feathers could be modified to represent exploits, for example, trimming the feathers to the quills and leaving «tiny fans » at their tips symbolized success at scouting. These feathers were « atremble even on the stillest days when men of duller sense feel no movement in the air ", and reminded the wearer that a " true scout » must be " ever more alert and aware than others " (Deloria 1988, p. 91). As Thunder Bear tells us: "The insignia signifying a successful scout are four eagle quills with their webs from the black tips down trimmed from the shafts and hanging, adorned with red bird plumes attached to the tips and worn erect at the scalp lock » (Walker 1991, p. 278). 
Beauty and feathers go together for the Sioux, and Lakota beauty was enhanced particularly through the use of feathers. "The taller Lakota men appeared even handsomer, their costumes more stunning, their stride more direct, their carriage more erect and regal ", writes Ella Deloria (1988) in Waterlily, an account of Lakota life through the eyes of a young woman. "All the men forming the front rank had on their splendid eagle-feather war bonnets, some round, the long plumes drooping gracefully about the shoulders, others with the long feather trailers that gently brushed and bent the grass behind the men as they walked along ", she writes. "For this was the Lakotas' headdress, and it lent a certain majesty to its wearer. Prairie Flower was proud to say, "Every man is a chief" " (Deloria 1988, p. 110) From this statement we can tell that Prairie Flower; Waterlily's sister, is clearly impressed by the "splendid eaglefeather warbonnet ", by the "long feather trailers ", and comments upon the " certain majesty " that is bestowed upon the man who wears such headdresses. To wear a " Lakota headdress » makes the wearer " handsomer », " stunning ", and " regal ». That " every man is a chief » when wearing feathers is a significant statement about the importance and meaning of feathers in Lakota culture. Feathers, in this account, satisfy the Lakota desire for beauty (Standing Bear 1978, p. 188). As items of symbolic value, each feather also represented particular values the Lakota hoped to foster (Deloria 1988, p. 90).

The special role of birds in Lakota society and culture is encapsulated in the story of Falling Star. In this tale, Falling Star originally appears on earth as a baby in need of a parent who will provide him shelter and nurture him as he grows up. As Black Elk tells it:

The magpie was a wing of the air, so he called strongly to the wings of the air, and all kinds of wings came - the eagle, hawk, buzzards, magpies, everything. The meadowlark came last. They all had a council, and the bird chief, the eagle, was there and presided over the council. (DeMallie 1984, p. 397)

The birds all speak first in this council meeting because it was the magpie that discovered the baby, thus giving them the right to speak first. The owl suggests that the snake be the one to raise the baby. The crow suggests the hawk should care for the baby because " he is always roaming around and is a rustler ». The havk defers, saying he has no kin, therefore everyone is an enemy to him. The kingbird suggests that the mud swallow take over the raising of the baby because " he has a nice home, it is all well daubed up and there is no way of the baby's catching cold». The kingbird makes his case for residence with the swallow because " he has the best home of all of us » (ibid., p. 397). The mud swallow, however, then refuses because he lives " high up under the banks ». The prairie chicken then suggests the eagle is the best choice because he is a good hunter and could always be counted on to protect the baby and provide food for him. But eagle does not agree because he lives too high up in the tree and it is too 
cold up there for a baby. The blackbird then suggests that the woodpecker is a good choice because his house is inside of a tree. The woodpecker claims his house is too small because he has a large family. Finally, the oriole, « the smallest of the birds », suggests the meadowlark would be a good choice because he has a " fine home » and « is good natured ». The meadowlark agrees to be the one who raises Falling Star. Black Elk comments: «I guess you all know how the meadowlark has his nest. It is on the ground and is built up all around. The meadowlark has his doorway facing east. The nest is built all nice and warm with grass » (ibid., p. 398). In this story, the birds express a variety of characteristics, such as residence type and location, appropriate family size, subsistence strategies, the importance of climate and temperature, and suitable aspects of personality. However, ultimately, it is the meadowlark who builds his nest in the manner most Sioux and therefore, most suitable for Falling Star to live with.

Having documented the integration of birds in a general yet distinctively Sioux context, in the following pages I pull together data for a variety of birds drawn from the ethnographic record.

\section{Crane (Lakota: phehán; Latin: Grus canadensis)}

The crane, according to Luther Standing Bear, could indicate the arrival of rain: « for the crane foretold wet weather by flying high in the air and coming down whistling all the way ». He is careful to differentiate the cranes on the plains from those cranes that are associated with water: « These birds were not water birds, but were prairie inhabitants having the common name of sand hill cranes ». However, he does not base his differentiation on the qualities of plumage or how they made their nests; rather, he writes that « their songs or whistled notes were quite soft and melodious and their bills were not the lance-like ones of the water heron. This bill was copied in the construction of the wooden love flutes of the Plains people » (Standing Bear 1978, p. 158)

\section{Crow (Lakota: kȟajǧí, ujčišičala; Latin: Corvus brachyrhynchos)}

Crow feathers make sure that the wearer takes the straightest path and does not lose his way (Standing Bear 1988a [1931], p. 71; Deloria 1988, p. 90; Walker 1991, p. 223). The crow, like the meadowlark, is featured in the story of the culture hero Falling Star. On his journey, Falling Star encounters a village of people who are starving because there is a "pure white crow that talks and it seems he is the one that keeps the four-leggeds away 》 (DeMallie 1984, p. 403). Falling Star transforms himself into a buffalo and lures the crow to his dead flesh in order to stop the crow from warning the buffalo when hunters approach. The crow, aware that the dead buffalo is actually Falling Star, eventually succumbs to temptation and begins to eat the flesh. Falling Star catches the crow and takes 
him back to the people. The crow is placed in a tipi and smoked until thought dead, transformed from pure white to black in the process. When the plug is removed from the top of the tipi, the crow manages to get one of his feathers through the hole; the feather turns into a black crow and flies away. According to Black Elk:

When he flew away, they all called for Falling Star to do something, but he said as long as the crow was black he had no power. He would never be white again, so he would not have any influence. So they went hunting. The black crow came hollering, but the buffalo would not pay any attention. (ibid., pp. 403-404)

In a later story, a young girl who was thought to be dead was placed upon a scaffold and left on the prairie by her parents. A crow spoke to her and told her that she would be rescued (ibid., p. 185).

\section{Duck (Lakota: mağáksiča; Latin: Aix sponsa)}

Consider that the green neck feathers of the mallard drake adorn the pipe and accompany the eagle feather in the "confirmation ceremony " (hunka) as a testament to the knowledge of the duck in the air and in the water (Standing Bear 1988a [1931], p. 71). Duck feathers give the wearer a stronger awareness when near lakes and streams (ibid., p. 71; Deloria 1988, p. 90; Walker 1991, p. 223). The green neck feathers of the mallard drake represented generosity and hospitality (Walker 1992, p. 106).

Eagle (Lakota: wayblí, wayblí gleška; Latin: Aquila chrysaetos)

A hunter who captured an eagle was entitled to wear the feathers (Standing Bear 1988a [1931], p. 89). According to both Luther Standing Bear and White Bull, the positioning of a single eagle feather can denote the order in which a person entered battle and "met the enemy " (ibid., pp. 84-85; Vestal 1984, p. 25). Women rarely wore feathers and «were not permitted to wear quill insignia [i.e., eagle feathers] except those who had lost near kindred in war ", and "such were permitted to wear the insignia that the lost ones were entitled to wear " (Walker 1992, pp. 62, 106). Eagle feathers bring success and power (Standing Bear 1988a [1931], p. 71; Deloria 1988, p. 90; Walker 1991, p. 223). According to Thunder Tail, when the Lakota wore eagle feathers, they became, in fact, eagles, hoping to acquire the abilities and powers of those birds: " Birds fly high in the air, and the people especially study eagles. Eagles are clear-sighted and wise. And because the people wish to resemble eagles, they wear eagle feathers in their hair » (Rice 1998, p. 162). The wearing of feathers as a representation of Lakota connection to eagles was an important aspect of non-verbal communication. Eagle feathers symbolize bravery, chieftainship, present and future success as a warrior, valor, virtue, potency, strength, vision, 
and « love of ceremony and dignity » (Walker 1991, p. 215; Standing Bear 1988a [1931], p. 78, 1978, p. 187). Eagle plumes (the fluffy feathers under the eagle's tail) add potency to a sacred rattle (Walker 1991, p. 233). In one Lakota myth, the eagle plume represents a force of nature - a whirlwind - that will rescue a warrior if he finds himself in danger. When he finds himself in trouble, the warrior calls out to the woman who gave him the eagle plume and a whirlwind appears and carries him to safety (Walker 1989, pp. 111-112). In another myth, a character attaches eagle plumes to his ankles and is able to travel faster than "birds can fly " and can walk from hilltop to hilltop with a single step. The character shares the power of the eagle plume with others who then are able to walk from hilltop to hilltop just as he can (ibid., pp. 312, 316). The idea that tying on eagle plumes can give supernatural powers exemplifies the link between the Lakota, birds, and religion.

The eagle plume also represented purity (Walker 1992, p. 106). Eagle plumes were even thought to represent the breath of life itself: plumes were tied to eagle bone whistles that were placed in the mouths of sundancers so that the breath of the dancers would be visible to onlookers as the dancers kept time to the drum, « as if [the plumes] were alive » (Deloria 1988, p. 121). Owls and eagles were said to be the akicita (messengers) of the Sun and their feathers carried in them the tonwan (power) of the Sun, a spiritual property that can be transmitted through a messenger of a supernatural being (Walker 1991, pp. 118, 223). The down of water birds and plumes of eagles were said to form the bed of the East Wind who inhabits an island "where the Sun begins his daily journey to view the world " (ibid., p. 126).

\section{Hawk (Lakota: čhetán, čhayšká; Latin: Buteo jamaicensis)}

One who is entitled to wear hawk feathers has « much power to do mysterious things » (ibid., p. 223). The hawk was noted primarily for its hunting abilities and its affiliation with Crazy Horse. Black Elk writes: « The life of an Indian is just like the wings of the air. That is why you notice the hawk knows how to get his prey. The Indian is like that. The hawk swoops down on its prey; so does the Indian " (DeMallie 1984, p. 317). Luther Standing Bear comments that Crazy Horse exhibited characteristics of the hawk:

He was as sure and swift as the hawk himself. The hawk soars above a flock of birds and, darting down in their midst, sends a luckless bird to the ground. The hawk may be cruel, but he is feared by most birds. Whether the medicine man told Crazy Horse to wear the hawk, I do not know, but at any rate he was as fearless as the hawk. (Standing Bear 1988a [1931], p. 89)

Further, Crazy Horse "always wore a hawk at the side of his head". Standing Bear believed that Crazy Horse was widely « worshipped for his ability, 
amounting almost to magic, and for his superb knowledge of strategy in warfare ». Crazy Horse used the powers associated with the hawk to live « a charmed life with the aid of the dauntless hawk » (Standing Bear 1978, p. 178). And although the people observed that Crazy Horse used the powers of the hawk, he never "claimed to be a medicine-man ». This connection between Crazy Horse and the hawk was largely due to the fact that he had « escaped so many dangers » (ibid.).

\section{Kingbird (Lakota: wasnásnaheča; Latin: Tyrannus tyrannus)}

In Black Elk's account of his vision it is the kingbird that lets him know that two men are coming and that he should be alert and listen to them (DeMallie 1984 , p. 109). The men, as messengers of the Wakan, after delivering their message then transform into geese (ibid.). The kingbird is also featured in one account of the ceremony that takes place when a tree is selected for use in the sundance. It is mentioned because: « the kingbird, though small, is feared by all its enemies » (Densmore 1992 [1918], pp. 112-113).

\section{Magpie (Lakota: unkčékhiȟa; Latin: Pica hudsonia)}

The magpie is important for the central role it played in the myth known as the Great Race. Because he won the race for the wingeds and the two-leggeds, he was taken (along with the culture hero Red Thunder) to see Wakinyan (the Thunderbird) and was rewarded with the right to "wear the rainbow ». Black Elk writes: "If you kill the magpie now, you will see that the end of the tail is the rainbow ». The magpie was also rewarded with the ability to travel in any season for « it could go as it pleased the year around, whether it was winter, spring, or summer » (DeMallie 1984, p. 310). Yata (the West Wind) is also associated with the magpie. During the time when the Gods were selecting which bird was to be associated with each direction, it was determined that the magpie would be the messenger of Yata because of its despicable traits: " It is an evil bird, an enemy of all other birds ». The magpie, he says « is a thief, stealing where it can, killing the young and helpless ». The bird " is a bird of ill omen and when seen as your messenger, it will foretell of trouble ». And in the tale, the magpie then is said to have entered a tipi and "befouled the inside of the lodge ". The magpie is then cursed with the task of having to build his nest not only for his own children, but for the children of others (Walker 1989, p. 335).

The magpie is also featured in another story where the people are starving and looking for food. In this story, Iktomi (the Trickster) tells the people to follow the birds that " fly before Yata », where they would find food " in abundance »; at the same time a medicine man told the people that he received a message in a vision that they were to follow one single bird, rather than a flock of birds. The nosy magpie listens to the people talking and attempts to communicate with them. 
Iktomi interprets the magpie's language and tells the people to follow the bird. Some of the people follow the magpie and do not find food. They return and with the medicine man then follow the snowbird (hupú wanblila), where they enjoy a pleasant journey and discover a source of clean water and a cache of food in a cave that had been stored there by « the squirrels, chipmunks, woodpeckers, and other creatures » (ibid., p. 371). It is also the magpie who finds the crying baby (who later becomes the culture hero Falling Star) «because he knows everything ». The magpie speaks to the baby, telling him that he will call all the birds and animals together to help « decide the destiny of Falling Star » (DeMallie 1984, p. 397).

\section{Meadowlark (Lakota: thašiyagmunka; Latin: Sturnella neglecta)}

The meadowlark is an important bird because it is most noted for having at one time been able to directly communicate with Lakota people. According to Luther Standing Bear, the meadowlark's ability to speak Lakota has to do with the level of social development and geographic location: « The larks in our State [South Dakota], at that time, talked the Sioux language - at least, we inferred that they did; but in California, where I now live, it is impossible to understand them. Perhaps they are getting too civilized». Additionally, the comments that meadowlarks would make to the people were not appreciated because people thought the birds were not friendly: «In our country, we little fellows thought these birds were our enemies, because they would say things to us that we did not care to hear ». In their attempts to communication with the people, meadowlarks would " call out a boy's name, and say that "his mamma wanted him", or some other objectionable expression in bird talk ». Subsequently, the people would avoid the meadowlarks and hope that they wouldn't come too close to them. However, he agrees that « those early songsters were wise birds, and sometimes we would hunt all day and get nothing » (Standing Bear 1975, p. 39).

The meadowlark is also featured in stories and myths. For example, at the feast prepared by Wohpe in honor of all the birds and animals, according to Wohpe's Grandmother, Wakanka, the meadowlark is the one that has the power to call all of the birds (Walker 1989, p. 364). Further, in the story of the culture hero Falling Star, the meadowlark adopts Falling Star, brings him home and his wife is delighted to have a new grandson to raise. Falling Star is nurtured and cared for, and within four days he has grown from baby to young boy: the first morning he was sitting up, the second morning he was crawling, the third morning he was walking, and the fourth morning meadowlark and his wife awaken to discover that Falling Star is outside of the tipi playing (DeMallie 1984, pp. 398-399). Meadowlark teaches Falling Star to use a bow and arrows, and over the next four days he brings home a beaver, two jackrabbits, a young deer, and a buffalo calf, over the same time developing into a teenage boy. Falling Star, in the 
care of meadowlark and his wife, is soon a young man whose sharing of the liver of a buffalo calf is memorialized in the refrain of the meadowlark:

The liver was good eating. Meadowlark got on top of his tipi and announced: " My grandson brought me a good buffalo calf liver. The calf liver is rich ». To this day you hear the meadowlark saying: " pti-hin-chla pinapin [ptehincala pi napin], "calf liver rich!" " They had a lot of papa [dried meat] made, because the grandson had provided so well for them. (ibid., p. 399)

Additionally, while on a journey during the winter later in his life, a meadowlark in the form of a man appears to Falling Star and gives him the power to turn himself into a four-legged (along with a prophecy of the future that suggests he will need to transform himself into a four legged, who will then die, and be reborn (ibid., p. 402). The lark has a social disposition and heralds the change of seasons: " The lark is cheerful and brings the warm weather " (Walker 1991, p. 249).

\section{Swallow (Lakota: ičápšinpšinčala; Latin: Hirundo rustica)}

Swallows were known for "their swift and bold darting here and there ", causing warriors to seek to imitate their movements while in battle. The presence of flocks of swallows « flying audaciously about » could also signal the arrival of a rain storm. "While it rained we saw no swallows ", writes Luther Standing Bear, « but as soon as it had gone, again would come the swallows more hilarious than ever » (Standing Bear 1978, p. 158). A single swallow, inscribed upon the shield of a heyoka (Contrary) warrior, is considered to be a representative of the Thunder Being (Wakinyan): « The shield is ornamented in compliance with the communication given by the swallow, the messenger of Wakinyan » (Walker 1991, pp. 279; 1989, pp. 81, 319). In Lakota mythology, when Yata and Eya go looking for Wakinyan, the swallow speaks to them, tells them that he is the messenger of the Winged One, and explains the actions of a heyoka as doing and saying the opposite of what one would normally say and do as a way of expressing contrariness (Walker 1989, p. 81). Further, the swallow (as well as a snow bird. Lakota: hipu wayblila; Latin: Plectrophenax nivalis), could cause a young man to believe he was destined to be heyoka, for if he saw a swallow in his vision, it was determined that he was to be heyoka (Walker 1991, p. 101).

The swallow plays an instrumental role in Lakota cosmology as the messenger of Wakinyan, the Thunder Being, who is often portrayed as an immense grotesque and misshapen bird. The swallow, as an intermediary, introduces Eya to characters to Wakinyan, who is described as follows:

Like a cloud of smoke, there arose from the top of the great lodge a thing without shape. It had two wings and there were four joints in each wing. Its huge talons opened and when they closed, they were hidden. It had one eye. It opened its eye and glanced at the 
tree. The glance was like a flash of fire and the tree was destroyed. It opened its huge beak and there were four rows of sharp teeth in it. From its throat came a crash and a roar. It beat on the clouds and they rumbled. (Walker 1989, p. 82)

In the account from Walker (ibid.), the swallow questions Eya, asking him if he wants to risk the harm and consequences of looking at Wakinyan, which include a commitment to be the companion of Wakinyan and to « aid him in taking from the world all filthy things ». Wakinyan, who, finding himself pleased with Eya, transforms into human form and takes the identity of the God Heyoka, then exhorts:

Together with you, I will purify the world from all filthy things. We will sweep it and wash it and water the ground. We will cause all that grows from the ground to flourish and bear leaves, flowers and fruits. We will give nourishment to all that breathes and cause their growth. (ibid., p. 320)

The God Heyoka (in the form of a man), who is also simultaneously Wakinyam, lives in a cedar tree. He selected this tree as it is the progenitor of all the trees in the world (« all others coming from it and it has lived from the beginning and will live forever ») (ibid., p. 321). HeyokalWakinyan makes his nest in the cedar tree and in the nest is a large egg from which his " young " are everemerging. He says that he uses his young " as drum sticks » and the sound of thunder ("drumming ») is said to be his voice » (ibid.). After this exchange, the swallow reappears and tells Eya that as each of the brothers choose a particular direction (north, south, east, or west), they are to put a stone on the ground in that direction and keep watch over it until a bird lands there - it is this particular bird (and all of its progeny) that will become the messenger of that specific direction (ibid.). For example: "In the draft in file folder 12, Colorado Historical Society, the brothers choose their avian messengers before starting to establish the directions. Yata chooses the magpie, Eya the swallow; Yampa the owl, and Okaga the meadowlark ", writes the editor, Elaine Jahner, in a footnote (ibid., p. 401).

Later in the account, it is the swallow that confirms to the sons of Tate that their prayers have been heard and the decision has been made about who would have the position as oldest son. Yata (whose messenger is to be the magpie) is not pleased by this and tries to throw a stone at the bird and becomes immobilized (ibid., p. 328).

\section{White Goose (Lakota: mağá, mağášapa; Latin: Branta canadensis)}

The white goose is documented primarily in the account of Black Elk's vision. Black Elk sees the second grandfather of the north who tells him he will 
"represent the wing of the great giant that lives " and subsequently sees this grandfather transformed from a man into a white goose. He looks then to the white horses and sees that they too have been transformed into white geese:

The second grandfather said: « Behold then, your grandfather, for they shall fly in circles from one end of the earth to the other $»$. [Through this power of the north I will make everybody cry as geese do when they go north in the spring because the hardship is over.] (DeMallie 1984, p. 117)

In Black Elk's vision, he is given the power of the geese, as they fly in four circles over each direction - north, south, east, and west - singing. The geese then demonstrate their call, which Black is to imitate in those situations where he felt the need to call upon their power:

As they went around, the geese called thus: « B-p-p-p, b-p-p-p! » [On earth Black Elk is to make the goose sound and he will get the goose power.] The western spirit said: "Behold them, for they shall have a sacred voice for you ». Here I was presented with the power of the goose voice. (ibid., p. 138)

Black Elk is later saved by his goose power as he flees the soldiers' gunfire after Wounded Knee during the fight at Drexel Mission. He finds himself on a hill with the enemy close to him. During this moment, he remembers the power that was given to him in his vision and imitates the call of the geese to evoke the power. He says: "Then I recalled my vision, the north where the geese were; then I outstretched my hands [and my rifle] and then made the goose sound ». Upon making this sound, "They pumped away at me from the creek then, but not a single bullet came near me - they couldn't hit me ». However, shortly thereafter; he is wounded when he forgets to make the goose call to invoke the power: « Then something hit me on the belt on the right side " he says. He attributes being hit with a bullet to the fact that he had not remembered to invoke the power by making the sound of the geese from his vision: «I was in fear and had forgotten my power. I had forgotten to make the goose sound there and to keep my hands up. I doubted my power right there and I should have gone right on imitating the goose with my power » (ibid., p. 277). In his vision, too, Black Elk sees the six grandfathers present the maiden who represents the north with a white goose wing (ibid., p. 217). This act, the giving of the goose wing to the woman who represents the north, is repeated later in his life when he enacts his vision.

\section{Owl (Lakota: hinhán; Latim: Bubo virginianus)}

It was believed that owl feathers increase a wearer's vision (Standing Bear 1988a [1931], p. 72). A cap of owl feathers worn by a scout or a warrior is a testament to his bravery (ibid., p. 73). Owls were believed to be " especially sacred » for: 
The owl moves at night when men are asleep. The medicine-man gets his power through dreams at night and believes that his dream is clear, like the owl's sight. So he promises that he will never harm an owl. If he did so, his power would leave him. For this reason some medicine-men wear owl feathers. The medicine-man also regards the owl as having very soft, gentle ways, and when he begins to treat sick persons he is supposed to treat them very gently. So in night wisdom and in the manner of carrying itself the owl is greatly respected by the medicine-men of the tribe. (Densmore 1992, p. 181)

The owl was considered the messenger of Yanpa (the East Wind). Characterized in one story as "the lazy bird", the owl (supposedly like the East Wind), "prefers to sleep during day time and its cry is dismal and complaining » (Walker 1989, p. 340). Further, when the owl is seen in a vision, « it shall be the harbinger of discontent » (ibid.). However, because of its assistance to the East Wind, it was rewarded with the ability to « see better at night than during the daytime " and to " fly noiselessly » to enable it to sneak up on the small animals that become its prey (ibid., p. 345). According to Thomas Tyon, « when an owl hoots at night, the people believe that its call is very Wakan » (Walker 1991, p. 165).

\section{Prairie Chicken (Lakota: šiyóka; Latin: Tympanuchus cupido)}

Birds are even responsible for teaching the Lakota to dance and to sing. Birds, according to Luther Standing Bear, danced long before people did; in fact, they danced first (Standing Bear 1988a [1931], p. 68-69). Prairie chickens, he says, " appreciate time and rhythm », "form a circle with the leader at the center », step to the right " at the same time and the same speed », while making a sound " like the double beat of the tom-tom ». Their «feet, voices, and tails [rattles] » are « a great sight to see » (ibid., pp. 68-69).

\section{Woodpecker (Lakota: čhạkátotola; Latin: Melanerpes erythrocephalus)}

Head feathers of the red headed woodpecker represented two specific qualities: holiness and sincerity (Walker 1992, p. 106). According to Higheagle, the feathers of the woodpecker were used to decorate the sacred pipe during the ceremony designed to demonstrate a parent's love for a child, because it is: " a simple, humble bird, which stays near its nest and is seldom seen » (Densmore 1992, p. 71). Of her observation of this ceremony, Frances Densmore (ibid.) wrote: « This bird seems to have been considered especially appropriate, because children who underwent this ceremony were more closely guarded and protected than others " . 


\section{OF THE KINSHIP OF HUMANS AND BIRDS}

Further evidence for a special relationship between birds and humans is found in Lakota perspectives on spirituality and ritual. In the retelling of the gift of the sacred pipe to the people found in Joseph Epes Brown's The sacred pipe: Black Elk's accoumt of the seven rites of the Oglala Sioux (1989), White Buffalo Woman explains every part of the pipe and its adornments to the Lakota. The pipe bowl is a symbol of Mother Earth, the figure of the buffalo calf carved in stone upon it stands for the buffalo (and all the four leggeds), and the stem is said to resemble " all that grows upon the Earth ». When she gets to the feathers that are attached to the spot where the bowl and stem converge, she says: « these twelve feathers which hang here where the stem fits into the bowl are from Wanbli Galeshka, the spotted eagle, and they represent the eagle and all the wingeds of the air ». She says further: " All these peoples and all the things in the universe are joined to you who smoke the pipe - all send their voices to Wakan-Tanka, the Great Spirit ». She intones: « When you pray with this pipe, you pray for and with everything " (ibid., p. 6). In the act of smoking the pipe, then, a relationship is created between all things that are part of the earth, walk on the earth, or fly around the earth. This bond of solidarity between two-legged, four-legged, and winged (that represents the conjoined voices of all things human and non-human) is then manifested upward as a communal prayer to Wakan-Tanka through the smoke of the pipe. Ella Deloria provided further understanding for this act: «The Dakota words "to address a relative" and "to pray" are familiar everyday words", yet in practice "they are one" (Deloria 1944, p. 28). The smoking of the pipe, expressed by Deloria as " wacekiya » is to be interpreted as establishing kinship such that « it is the open-sesame to any sincere exchange of sentiment between man and his neighbor or man and his god " (ibid., p. 29). Thus, the incorporation of all things into the pipe combined with the smoking of the pipe was both an appeal and the creation of a kin relationship between those sending up the prayer and the combination of forces represented by WakanTanka who might then provide an answer. As Deloria (ibid.) says it: " to smoke ceremonially is to wacekiya $»$.

Lakota notions of relatedness are grounded in their understanding of kinship: « for the Sioux, kinship is not confined to the classification of relationship through links of marriage and descent, but it is more broadly defined to embrace all significant social interaction » (DeMallie 1994, p. 126). This notion is further confirmed by Harrod (2000, p. 135) when he writes: « Northern plains peoples believed that animals were kin, but they also believed that animals were different than humans ». Harrod goes on further to comment that rituals included « visions of kinship » that displayed the interrelatedness of plains culture between humans and non-humans, thus constituting "endless 
expressions of life » that comprise a "profound kinship among all of us ». $\mathrm{He}$ suggests that we « must imagine a new paradigm that would express, through ritual action, the religious significance of these forms of interdependence of life upon life » (ibid.). A quote from Fools Crow (Mails and Chief Eagle 1990) illustrates this concept in action: « In Sioux understandings, any religious action or item $i$ is the thing spoken of rather than simply a representation of it 》 (ibid., p. 242).

The story of Falling Star and the belief that birds are kin, and thus, relatives, is made clear by Black Elk when he says: "That is why the Indian is always feathered up; he is a relative to the wings of the air " (DeMallie 1984, p. 317). While birds are generally considered fellow « two-leggeds », they are also widely believed to be messengers of Wakan-Tanka and full participants in the process of living life in cooperation with all the forces of the universe. This sentiment is expressed by Luther Standing Bear: «As all animals and all birds are useful to the Indian and share with him some of their secrets, the Indian has a friendly feeling toward all creatures ». Further, he comments that underlying this « friendly feeling » is the belief that "he and all other things of earth are unified " (Standing Bear 1988a [1931], p. 52). Birds were seen as co-participants and also as pathways through which one could access specific powers associated with the particular bird. Luther Standing Bear explained this by suggesting that individuals were able to connect to the life force within the world around them - both within objects that were animate (birds) and within those that were not (rocks, rivers, cliffs, trees). It is through the incorporation of the energy and power in these phenomena into the individual by the act of seeking out those forces, according to Luther Standing Bear «so we felt the power within us grow » (ibid., p. 159).

Although there were a variety of ways these powers could be accessed and incorporated, the most prevalent method seems to have been the act of crying for a vision. "This way of praying is very important ", writes Black Elk, " and indeed it is the center of our religion " (Brown 1989, p. 44). When an individual received a vision as part of this ritual, then he « actually identifies himself with, or becomes, the quality or principle of the being or thing which comes to him in a vision, whether it be a beast, a bird, one of the elements, or really any aspect of creation " (ibid., p. 45). The particular bird in the vision is in a form identified with a bird the individual may have seen outside of the ritual context, yet « the animal and birds, and all things, are the "reflections" - in a material form - of the Divine principles » (ibid.). Luther Standing Bear (1988a [1931], p. 160) confirms this when he writes: « It is in this sleep [the vision quest] that the Great Mystery comes to him in the form of some bird or animal and talks with him. They have come to impart to him a secret of value and to share with him some of their power. Sometimes they bring a fetish of some kind or an herb or root that has great healing power, or it may be a song to sing at the bedside of the sick. But whatever is brought is useful and powerful ». Once the individual sees a 
particular bird (or other animal, symbol, etc), he is reincorporated into the community and is known as a « dreamer », and is able to access the power given to him in the vision (ibid., p. 161).

Each specific bird had a set of characteristics that was beneficial to the Lakota and in turn could be used for healing purposes. There were medicine men whose power was derived from birds and these men « resorted to jugglery such as sucking through a bone and tricks of various kinds » (Walker 1991, p. 105). It is important to remember that Luther Standing Bear's introduction to religious belief began with his first kill of a small bird. His father, hoping Standing Bear would become a warrior, had appealed to Wakan-Tanka to assist his son « to shoot straight », thus giving Standing Bear his first introduction to the cycle of prayer and sacrifice, as his father gave the dead bird to a poor old man (Standing Bear 1975, p. 10).

Evidence therefore suggests that the notion of a special relationship with birds was acted out in multiple ways and integrally related to the cognitive world of the historical Lakota through their likening of their lifeways to the behavior of birds. In the next section, I combine myth and historical evidence following Lévi-Strauss's Osage example to merge the synchronic reality of myth with the diachronic reality presented by such evidence.

\section{THE HISTORICAL RELATIONSHIP BETIVEN HUMANS AND BIRDS}

Drawing directly from The sixth grandfather (DeMallie 1984) and other historical sources, in The great race of the birds and animals children's author Paul Goble (1985) tells the story of how « mankind won power over buffaloes and all other animals, and with this power we [the Sioux] were also made the guardians of Creation ». In ancient times, humans were eaten by buffaloes. The people prayed to the Creator for relief and he sent the crow to gather all the beings on earth together in one place. When all had come together, he informed them that there would be a race between the «four leggeds» and the "winged». Whoever was to win this race would have the power to eat the other. So the people paired up with the birds, and the buffalos paired up with the animals. « The birds flew ahead like arrows », writes Goble, but Magpie (one of the slower birds) "flew down and sat on Buffalo's back ». The race was close; the animals become more and more distracted or tired, the human in the race gave it all he had, and " Buffalo was almost exhausted ». Just as Buffalo neared the finish line, Magpie leapt up off of Buffalo's back and won the race. This gave the Lakota the power to eat the buffalo and since that time " nobody ever harms Magpie ». Also since then, the Lakota have demonstrated their honor for the « winged » by decorating themselves with feathers. Goble writes: « We can all be a little like the birds: they leave the earth with wings, and we can also leave the world by letting our thoughts 
rise as high as the birds fly ». Magpie's tail, it is said, is represented in the « iridescent colors » of the sun (Goble 1985).

Another myth, "How the Sioux nation was born », originally recorded in Reese (1960 [1941]) and reprinted in Powers (1977), refers to a time when the Lakota faced extinction from a great flood that forced them to flee from their ancestral homelands. Those who drowned in this flood were transformed into catlinite. Through the ongoing tradition of carving pipebowls from catlinite these ancestors are symbolically incorporated into the pipe. Only one Lakota woman survived the flood. She was rescued by a male eagle and taken back to his nest in a " great tree on a cliff above the water ». This union between the eagle and the Lakota woman produced a pair of twins; two children who were metaphorically not fully human and not fully bird. The twin children ensured the survival of the Lakota people on this earth. Eagle feathers, it is said, are worn as a representative embodiment of the ancestral connection: the father as eagle (Powers 1977, p. 85). This, then, is one explanation for the strong relationship that the Lakota share with the eagle, and by extension, birds.

Further evidence for this relationship with birds at the birth of the Lakota nation comes to us from the story of White Buffalo Woman. In various accounts of this myth, the pipestone represents the earth and is decorated with a buffalo that symbolizes the kin relationship of the Lakota to animals. The pipe is decorated with twelve feathers that symbolize the relationship of the Lakota to the eagle and, therefore, to all birds (Brown 1989, p. 6). White Buffalo Woman reveals to the Lakota that the action of smoking the pipe fuses the material and non-material world together and constitutes an obligatory relationship between the eagle (as ancestral father and grandfather) and the human (as ancestral mother and grandmother) (ibid.). This act of expressing the relationship between the Lakota and the eagle is reaffirmed consistently whenever smoking the pipe (be it ritually or in everyday life). Following this origin story, by extension, it could be said that the entire Lakota nation is engaged in a kin relationship with the spotted eagle that began at the birth of their ancestors after the great flood, a kinship that is ritually reaffirmed every time the pipe is lighted. Other myths suggest the integral relationship between humans, birds and their feathers, and the role that birds (in the form of their feathers) play in connecting Lakota people to the non-material world. Feathers as well as the entire bodies of birds can be utilized as both prayer and offering, for Black Elk tells us that he wore the skin of a red bird on his head as he entered battle (DeMallie 1984, p. 188). In one myth, the presence of a red plume on an invitation wand indicates to all that spiritual matters will be discussed at the meeting: "Okaga made the invitation wands; twice as long as his foot meaning to travel with both feet; decorated with bright colors meaning a joyous festival; tipped with a red plume meaning that Wakan business was to be discussed » (Walker 1989, p. 158). Birds were largely considered to be messengers of Wakan, entities that move between 
the material and the non-material world. Given this evidence, apparent from myth, it is possible to tentatively conclude that the historical Lakota envisioned themselves as related to birds (and other animals) in a close relationship, thus representing a form of kinship. This kin relationship was one path through which they could access the power of the Wakan and connect themselves to the non-material world.

Following Lévi-Strauss's Osage example, this synthesis attempts to demonstrate the level of integration present between myth and reality, and how myths functioned to shape and impact the lived experience of Lakota people. The exodus of the Lakota from their ancestral homelands to escape both flood and extinction caused the death of many of the people. These people became part of the earth and were transformed into the catlinite that has historically been used for the sacred pipe. While others did not survive the flood, a male eagle rescued a single Lakota woman from the rising waters and took her back to his nest, which was located on a cliff high above the floodwaters in a majestic tree. While she remained in his nest, the male eagle and the Lakota woman engaged in sexual intercourse and the woman became pregnant with twins. These twins are responsible for the survival of the Lakota. As a result of their mother being saved by the eagle, all Lakota people, therefore, consider themselves to be descended from the union of an eagle (as father) and a Lakota woman (as mother), and the men wear eagle feathers as a visible symbol of their connection to the eagle as their father. Lakota women, as a symbol of their connection to the original Lakota woman who was rescued by the eagle, are responsible for maintaining the "nest ", so to speak. In mythic time, there are no barriers to communication between Lakota and birds; they speak the same language. Birds like the prairie chicken, meadowlark, and crow speak in words that are understandable to the Lakota. It was the prairie chicken that taught the Lakota how to dance because when they dance they form a circle around a leader, make similar motions and sounds, and use their tails as rattles. In ancient times the buffalo had power over the Lakota and would eat them. The people prayed to the Creator and the Creator heard their prayers. Through the crow, he called every living thing together and proposed that the four legged animals race the two legged beings, and whichever would win this race would have power over the other. Due to the cleverness of magpie, the two legged beings won the race. Thus, the Lakota now have power over the buffalo and they wear feathers of birds to remind them of how Magpie helped them to win the race. Magpie's tail became part of the sun.

The appearance of White Buffalo Woman may be considered a continuation of the account. By this time, the Lakota could no longer communicate directly with animals and birds. White Buffalo Woman introduces the pipe to the people. She instructs them that the pipestone represents the earth and also the blood of those Lakota who did not survive the flood, that it should be decorated with a buffalo to remind them of their relationship to animals, and that it should be 
decorated with feathers to remind them of their relationship to eagle and all birds. She tells them that when they smoke the pipe, it recalls and renews their human and non-human origins, serving to reaffirm the obligatory kin relationship between non-human/eagle/father and human/Lakota/mother. She tells them that when smoking the pipe they should also offer it to the spotted eagle because the spotted eagle is a direct messenger to Wakan (in addition to offering it to all six directions).

Just as they honor the spotted eagle in ritual, the Lakota also mimic the behavior of birds in their domestic life as well as in wartime activities. Their tie to a common ancestor prompts them to make their camps in order to symbolically resemble nests, to locate their camps in places where there is an accessible food supply, to abandon these metaphorical nests when the food source dwindles, and to protect their children against other predators in the same manner that birds do. While the female Lakota stays home (in the " nest »), the male engages in conflict with other groups, much as birds do, earning his feathers for exploits in this arena and bringing them home (as well as other gains from these activities) to honor Lakota women. Feathers, and the wearing of them, allow the Lakota to identify what kind of «bird » a man is; and the feathers of the eagle allow a man to become a closer representation of this connection to the common eagle ancestor that all Lakota share.

The fusion of myth with historical evidence suggests that the integration of human and non-human elements in Lakota social organization results in a complex, culturally significant narrative that allows for a small glimpse of the interconnected network of symbols, as suggested by DeMallie (1989, p. 389). Descent from two common ancestors is incorporated into myth and experienced in reality. Historical evidence (diachronically informed) when combined with myth (synchronically related) brings us to a deeper understanding of the relationship between Lakota and birds, one that is contextually meaningful and perhaps gives us a unique departure point for a more complex understanding of kin relationships in a distinctively Lakota context.

\section{BIRDS AS PERSONS AND CONSUBSTANTIALITY IN WAKAN}

Luther Standing Bear considered feathers to be the ultimate embodiment of a Lakota aesthetic or philosophy of life. Birds and their feathers played an instrumental part in this continued ceremony of existence. He suggested that Lakota aesthetic life was manifested through « song, music, dance, rhythm, grace of motion, prayer, chant, ritualism, color, body decoration, and symbolic design ». Lakota culture was based on those activities, and "tribal culture culminated in ceremony ». Further, he believed that " to be instructed in ritual and ceremony was to be an historian of the tribe » (Standing Bear 1978 [1933], p. 213). By the evidence as presented, birds, feathers and other symbols were 
an integral part of ceremonial life and ceremonial life was about the merging of the sacred and profane worlds. To become a teacher of these religious activities constituted the transference of tribal knowledge, that is, history as it was understood by the Lakota and not how it was understood in the Eurocentric mind.

Through ritual and ceremony, I argue that the Lakota were able to access the axe animique, becoming themselves as if birds; intermediaries between the seemingly material and the non-material worlds through this activity, representing a continuous intercession between man and the non-material world, ultimately integrating themselves completely into Wakam. Similarly, they were constantly living out their known and believed history. Feathers symbolized various concepts of a distinctly Lakota aesthetic that incorporated the human and the non-human worlds into one holistically driven complex system of symbols and experiences. We can conclude that birds (often represented by their feathers) were engaged in an ongoing social relationship with the Lakota, one that was inherently consubstantial with the natural and social world in which they lived.

Perhaps the best example of this extant form of consubstantiality in Wakan is the yearly world renewal ceremony known commonly as the Sun Dance. In the Sun Dance, the imagery and symbolism associated with birds and their feathers was a direct connection to the sun and was present in the preparation of sun dancers, each with " an eagle feather in his hair ", "some wear[ing] bonnets ", and others " wear[ing] a wreath of sage grass with a black feather on each side representing horns ». Each man also had the following items: an eagle bone whistle and an eagle feather wrapped in sage (Walker 1992, p. 98). As demonstrated in Figure 1, this reverence for birds symbolized a direct link to Wakan, a symbolic link to the non-material world, sensitivity to one's surroundings, reliance upon birds and animals, and an alert and aware relationship between the Lakota and the natural world (Standing Bear 1988a [1931], pp. 70-76).

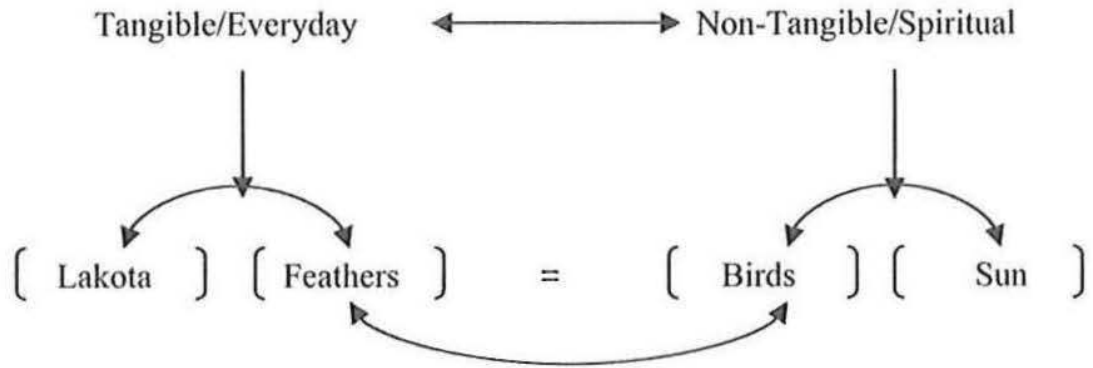

FIG. 1 - The relationship between the Tangible/Everyday and the Non-Tangible/Spiritual as expressed through Feathers/Birds. 
Clearly, more research is needed to analyze the ways the characteristics and behaviors of birds were represented in Lakota conceptualizations of kinship, as well as other aspects of study like religion and social organization. Birds and their feathers, it is clear, are an integral part of the Lakota cultural system; not merely decorative items that may adorn a pipe or entities that fly above. Having documented the multiple meanings of feathers in Lakota life and the transformative qualities of feathers (as well as birds), my analysis has demonstrated that birds and their feathers represented the presence of a symbolic and significant relationship between the material and non-material cognitive worlds in Lakota culture. We find that birds have been essential to the Lakota people and the relationship between the Lakota and birds becomes visible through a sampling of a few relevant myths that are culturally constituted through ritual, ceremony, and everyday life. If we were to consider birds as entities that move freely through the sky and serve as messengers to the sun, we could then consider the Lakota as people who move freely upon the earth and share a relationship with the sun in a similar fashion. Like birds, they build their nests in places where there is an accessible food source nearby and move their nests when their food source dwindles. Perhaps nowhere is this connection made more explicit than in the individually chosen practice of piercing the sundancers as part of preparation for the ceremony. Done on the third and fourth days of the ritual, the quill end of the tail feathers of the golden eagle may be inserted underneath the dancer's skin, six on each arm, from the shoulder down toward the elbow, as if each man were transformed into a bird and acting as a messenger on behalf of the whole Lakota nation seemingly in kinship and communion with the sun (Mails and Chief Eagle 1990, p. 137).

This paper represents an attempt to delve deeper into the relationship between Lakota and birds. By articulating the connectedness of birds in Lakota life, this collection of data about the crane, crow, duck, eagle, hawk, kingbird, magpie, meadowlark, owl, prairie chicken, swallow, white goose, and woodpecker suggests that birds - whether observed in real life, myth, or as represented through their feathers and other adornments - played an instrumental role in the way in which the Lakota perceived the world around them. Birds (and other animals) set valued examples and provided access to powers in the universe that were integral parts of social and religious life. Moreover, it is clear that birds were persons to the Sioux. As persons who spoke Lakota, they would be considered kin before they would be considered enemies (DeMallie 2009, p. 189). Consequently, I believe that past anthropological analyses of kinship in American Indian groups are too theoretically narrow to take into account the entire symbolic system that lays beyond Eurocentric ideas of what Lakota kinship should be, and too historically charged to be of use in the discussion of relationships between humans and those entities considered to be non-human in Western thought. As a step toward this new understanding, I am inclined to suggest that birds and their 
feathers are an integral part of the Lakota cultural and symbolic system, not merely decorative items that may adorn a pipe or entities that fly above. After this sustained inquiry, here, then, I present evidence contrary to Durkheim, who stated:

Men did not come to believe they had duties toward the animals of the totemic species because they believed them to be kin; instead, they imagined that kinship in order to explain the nature of the beliefs and rites of which animals were the object. The animal was considered man's relative because it was a sacred being like a man; it was not treated like a sacred being because people saw him as relatives. (Durkheim 1995 [1912], p. 234)

Given the wealth of evidence available for the Lakota, it is more than possible that men did see animals as relatives and as a result of this relationship they had a particular sense of kinship. It is because they were " related ", and because the Sioux defined themselves as a society and culture through the process of relating to one another, that they considered themselves and in this case, birds, as fellow sacred beings that were related to Wakan. Ultimately, to be in relationship with one another and with the sacred meant that all beings were engaged in the totality of social relations that made Wakan possible; thus, all things are related. Perhaps, then, it is just as Black Elk says: « [T]he spotted eagle is really within us » (Brown 2007 [1947]). *

* Manuscrit reçu en février 2008, accepté pour publication en mars 2010.

\section{REFERENCES CITED}

Brown Joseph Epes

1989 The sacred pipe: Black Elk's accoumt of the seven rites of the Oglala Sioux, University of Oklahoma Press, Norman [1953].

2007 The spiritual legacy of the American Indian: commemorative edition with letters while living with Black Elk, World Wisdom Inc., Bloomington [1947].

Deloria Ella C.

1944 Speaking of Indians, Friendship Press, New York.

1988 Waterlily, University of Nebraska Press, Lincoln, NE.

DeMallie Raymond J.

1974 "Review of My People, the Sioux ", Ethnohistory, 21 (2), pp. 178-179.

1982 "The Lakota Ghost Dance: an ethnohistorical account », The Pacific Historical Review, 51 (4), pp. 385-405.

1984 The sixth grandfather: Black Elk's teachings given to John G. Neihardt, University of Nebraska Press, Lincoln, NE.

1994 "Kinship and Biology in Sioux Culture », in Raymond J. DeMallie and Alfonso Ortiz (eds), North American Indian anthropology: essays on society and culture, University of Oklahoma Press, Norman, pp. 125-146. 
2009 "Community in native America: continuity and change among the Sioux », Journal de la Société des Américanistes, 95 (1), pp. 185-205.

DENSMORE Frances

1992 Teton Sioux music and culture, University of Nebraska Press, Lincoln, NE [1918].

Désveaux Emmanuel

2001 Quadratura Americana: essai d'anthropologie lévi-straussienne, Georg Editeur, Geneva.

DURKHEıм Émile

1995 The elementary forms of religious life, The Free Press, New York [1912].

GoBLe Paul

1985 The great race of the birds and animals, Bradbury Press, New York.

HARROD Howard L.

2000 The animals came dancing: Native American sacred ecology and animal kinship, University of Arizona Press, Tucson.

Hurtado Albert L.

1985 «Review of Lakota Society », The Public Historian, 7 (3), pp. 115-116.

\section{LÉvi-Strauss Claude}

1962 Le totémisme aujourd'hui, Presses universitaires de France, Paris.

1966 The savage mind, The University of Chicago Press, Chicago.

Mails Thomas E. and Dallas Chief EAgLe

1990 Fools Crow, University of Nebraska Press, Lincoln, NE.

POWERs William K.

1977 Oglala religion, University of Nebraska Press, Lincoln, NE.

REESE Montana L.

1960 Legends of the mighty Sioux, Fantab Inc., Sioux Falls [1941].

RICE Julian

1998 Before the Great Spirit: the many faces of Sioux spirituality, University of New Mexico Press, Albuquerque.

STANDING BeAR Luther

1975 My people, the Sioux, Earl A. Brininstool (ed.), University of Nebraska Press, Lincoln, NE [1928].

1978 Land of the spotted eagle, University of Nebraska Press, Lincoln, NE [1933].

1988a My Indian boyhood, University of Nebraska Press, Lincoln, NE [1931].

1988b Stories of the Sioux, University of Nebraska Press, Lincoln, NE [1934].

Vestal Stanley

1933 "Review of Land of the spotted eagle ", The Mississippi Valley Historical Review, 20 (3), pp. 442-443.

1984 Warpath: the true story of the fighting Sioux told in a biography of Chief White Bull, University of Nebraska Press, Lincoln, NE. 
WALKER James R.

1989 Lakota myth, Elaine A. Jahner (ed.), University of Nebraska Press, Lincoln, NE.

1991 Lakota belief and ritual, Raymond J. DeMallie and Elaine A. Jahner (eds), University of Nebraska Press, Lincoln, NE.

1992 Lakota society, Raymond J. Demallie (ed.), University of Nebraska Press, Lincoln, NE. 